\title{
Religion, ethnicity, and the secular world
}

Paula Montero

\begin{abstract}
This paper explores the contrastive, or even contradictory, relations established between 'religions' and 'ethnicities' and what is by convention called the secular world in the conception of contemporary multicultural and post-secular democracies. When and why are 'religions' and 'ethnicities' perceived as a challenge to the political system? We draw on the literature that addresses the challenges posed by the growing presence of Muslim populations in Europe in order to analyze the confrontation in Brazil between Neo-Pentecostal and Afro-Brazilian groups. Our purpose is to understand why, differently from the European conflict, in which Muslim minorities are perceived as a simultaneously ethnic and religious challenge, conflict in Brazil occurs in a doubly inverted relation. Afro-Brazilian religions have built a positive relation to Brazilian nationality and have been acknowledged as religions by the State. In contrast, Neo-Pentecostal religions, although legally recognized, are weakly connected to Brazilian nationality.
\end{abstract}

Key-words: tolerance, multiculturalism, secularism, ethnicity.

\section{Resumo}

Este trabalho explora as relações contrastivas e até mesmo contraditórias que, na concepção das democracias multiculturais e pós-seculares contemporâneas, as 'religiões' e 'etnias' mantêm com o que se convencionou chamar de mundo secular. Interessa-nos compreender quando e por que 'religiões' e 'etnias' são percebidas como um desafio ao sistema político. Inspirados na literatura que enfrenta os desafios colocados pela crescente presença de populações islâmica na Europa, tomaremos como referência empírica de nossa análise alguns confrontos entre grupos neopentecostais e afrobrasileiros 
de modo a compreender por que, ao contrário do conflito europeu, no qual as minorias islâmicas são tomadas ao mesmo tempo como desafios étnicos e religiosos, no caso brasileiro o conflito se estabelece em uma relação duplamente invertida. As religiões afrobrasileiras conquistaram uma relação positiva com a nacionalidade e assim foram reconhecidas como religião pelo Estado. Em contrapartida os neopentecostais, embora legalmente reconhecidos, mantêm uma relação frágil com a nacionalidade.

Palavras-chave: tolerância, multiculturalismo, secularismo, etnicidade. 


\section{Religion, ethnicity, and the secular world}

Paula Montero

\section{Introduction}

Although ethnic and religious minorities can be perceived as presenting very similar social and political issues, they pose different challenges for liberal democratic thinking in that they interpellate public opinion and the actions of nation States in very different ways. Although particular historical contexts give this problem specific configurations, it is usually possible to affirm that while ethnic minorities put into practice grammars that concern the relations between racial conflicts, recognition, and citizenship, religious minorities put into play grammars that concern the relation between freedom (of speech and belief) and the sovereignty of State power. The political agendas of multiculturalism and secularism thus seem to have followed parallel routes in their political formation and implications. Some recent phenomena, such as the growing presence of Muslim groups in Europe and the expansion of Neo-Pentecostal Protestantism in Brazil seem, however, to cause these two agendas to converge, and thus make it necessary to rethink the consensus that has already emerged regarding secularism and the rights to difference. ${ }^{1}$ In effect, one of the characteristics that has made the Muslim issue so prickly for European liberal thought is that it seems to lead to an inconvenient convergence between multicultural demands for recognition and demands for religious freedom, thus generalizing the perception that Muslims interpellate the national States with demands for exception that, 
according to the Anglo-Pakistani sociologist Tariq Modood, are criticized for being politically unbearable, culturally considerably unreasonable and theologically foreign (Modood 2009: 164). As far as the Brazilian scenario is concerned, we would like to demonstrate that part of the discomfort caused by Neo-Pentecostal Protestant groups in the Brazilian public sphere also concerns the way in which their leaders connect the categories of ethnicity and religion from a political and ideological perspective. We shall draw on the dilemma posed by Modood in order quickly to revise the trajectory of these two currents of thought with the purpose of understanding the controversies $^{2}$ that emerge when the agenda for recognition confronts the agendas for secularism and freedom of faith.

But before focusing on the contemporary Brazilian scenario, let us briefly go back in time to understand better how the categories of 'ethnicity' and 'religion' have been associated with the modern construction of national and secular States.

\section{Ethnicity and religion in the construction of modern States}

\section{a. 'Nation,' 'race,' 'ethnicity'}

It can be generally affirmed that contemporary debate on multiculturalism represents an important unfolding of the anti-racial agendas of the $1960 \mathrm{~s}$ and 1970s. The historical relation between the constitution of the concepts of religion and race and the formation of state nationalities in the $18^{\text {th }}$ and $19^{\text {th }}$ centuries in Europe exceeds the scope of this paper. However, it is important to keep in mind that, as observed by Françoise Gaspard, every form of nationality is "a political construction that is established as a legal rule" (Gaspard 1993: 158, our emphases). Thus, 'nationality' defines who the 'nationals' are and, consequently, who is to have access to public and civil rights. In this play of forces, the production of conflicts of nationality generally operates through the elaboration of ascriptive categories such as land, blood, filiation,

\footnotetext{
$2 \quad$ We use the analytical notion of 'controversy' as elaborated within the project "Public Religions and Controversies: Experiences, Social Practices, and Discourse”, funded by Fapesp (Nr. 2011/02948-6). Although public debate is the empirical referent for this approach, it intends to propose an analytical model focusing mainly on a network of arguments that relates different agents and fields of knowledge. I am indebted to Eduardo Dullo and Andrea Peres for their comments, which have helped make the thread of my arguments clearer to me and the reader.
} 
race, religion, gender, etc. Such categories condition, on the one hand, the distribution of a set of civil rights (public employment, State benefits, etc.) and, on the other hand, the possibilities for certain social interactions. The literature on the subject observes that in $19^{\text {th }}$ century Europe basically two different models of nationality prevailed: the French model, which was based on the principle of universalizing citizenship that did not take ethnicity and religion into account, and the German model, based on the ideas of ethnic and cultural belonging. However, Gaspard observes that the right of blood has always been present, to a greater or lesser extent, in the legislations of all European national States. In this sense, they all contain a potential racializing dimension that might be mobilized in different circumstances.

The expansion of European States into other continents in the $19^{\text {th }}$ century made the political construction of nationalities even more complex. In effect, the different models of colonialism affected the way in which nationalities were distributed among extraterritorial populations. According to Gaspard, a law passed in France in 1865 , for example, excluded from the common law everyone who was designated as native [indigène]; thus, for over one century "it was possible to be French in Algeria without having access to all the attributes of nationality" (idem: 156). Similar processes of ascription occurred in the Portuguese colonial world, in which the indigenous African population was divided into 'natives' [indígenas] and 'assimilated' [assimilados] according to degree of 'civilization' and not color (Dulley 2013). In the British case, law distinguished between different categories of British citizens based on criteria of racial belonging; in the process, the name 'colored' was assigned to a very diverse set of 'racial'and 'inter-racial' possibilities. ${ }^{3}$

Although legal processes resort to historically available categories to assign nationality, the relations between the way in which law circumscribes categorizations and the way in which social life is organized in practice and social status (Christian, free, detribalized, taxpayer, etc.) were more determining in describing people than biological ancestry (which was difficult to recognize in colonial conditions). For the author, scientific thinking in the beginning of the $19^{\text {th }}$ century had natural history as its model and strived to transform the myriad of terms describing people and families based on their appearance and reputation into racial categories that could be organized into a systematic catalog of ancestries. The term 'colored' started to be used in local censuses in the early $19^{\text {th }}$ century in order to distinguish the free white population from the non-white population (including Indians) for taxpaying purposes. The pre-Civil War American society was, therefore, much more diverse from an ethnic and cultural perspective than the polarized society that was to emerge after the war, in which 'colored' was identified with 'black' with the dissemination of racism. 
are neither direct nor mechanical. In effect, 'nationals' are not produced by means of decrees. If the legal recognition of racial, ethnic or religious categories defines the scope of possibilities for social interactions, civil life is permeated by struggles for the rejection and/or recognition as well as redefinition of ascribed categories. The long tradition of the 'race' category, for example, in spite of the scientific criticism to which it was submitted already in the $19^{\text {th }}$ century, remained operative in European thought at least until the emergence of fascism even among those who opposed the idea of racial inequality. The concept of racism emerged in the debate that followed the disclosure of Nazi crimes and was originally used to fight the scientific claim related to the use of racial categories in order to differentiate people (Robert Miles 1993: 161). The ideology of the 'final solution' and its consequences, in addition to the struggles for decolonization that disclosed the violence perpetrated in the name of racial differences, contributed to accelerate the political and ideological disrepute of racial theories. UNESCO played an important role in the post-war period regarding the ultimate disappearance of race as a political category for naming differences based on biology. ${ }^{4}$

Michael Banton (1975) suggests that anti-racist civil movements were everywhere the precursors of the displacement of the category of 'race' by that of 'ethnicity.' However, it seems that such displacement became possible only when the 'race' issue started to be perceived as related to problems concerning the construction of nationality. In the American case studied by Banton, the alternative views of black nationality offered by the emergence of African States and the spectacular performance of their statesmen and diplomats in the international scene was fundamental for American blacks to be able to consider their own condition from a new perspective. For this author, even if discourses of nationality did not transform black Americans into a nation, at least it made them "more conscious of their difference" and thus allowed for their "ethnogenesis"s as a people or ethnicity. However, although the author is right in affirming that the relations between "ethnogenesis and

\footnotetext{
$4 \quad$ Although 'race' has progressively disappeared as a descriptive category, the notion of racism gained a new sense in the late 1970s, when it was disconnected from the notion of theory or ideology and started to designate institutional or personal practices of exclusion which do not present themselves as such. Robert Miles (1993: 163) considers the Black Power movement in the United States as a reference for the redefinition of the concept of racism.

5 This has been a current expression in France since the $19^{\text {th }}$ century. According to the author, it was recovered by Lester Singer in 1962 in reference to the American context.
} 
nationalism demand further investigation" (1975:158-159), it seems important to stress that it was only in the context of the weakening of classical nationalisms-a legal mark of reference for the entire $20^{\text {th }}$ century ${ }^{6}$-that the concept of 'ethnicity' started to be outlined as a political force. But this cannot be affirmed of modern nationalisms in which conflicts become part of the way in which the logics of the State operate.

It is interesting to note that in the Brazilian case, in contrast with the examples provided above, the categories of race and ethnicity have followed parallel routes: The political problem of blacks with regard to the production of nationality was dealt with based on the grammar of race and culture, while the indigenous issue was formulated in the field of ethnicity. Understanding why, differently from the United States, Indians were not classed as a race in Brazil and blacks were not ethnicized (except for the most recent cases of quilombolas) would deserve a separate investigation. What can be affirmed based on the available literature (Carneiro da Cunha 1986, 1987, 2009; Cardoso de Oliveira 1976; Farage 1991; Oliveira 1999; Monteiro 1994; Arruti 2006) is that the processes through which blacks and Indians were constructed as 'populations' in the Foucaultian sense (Foucault 2008)' are historically to be distinguished regarding the way in which these collectives were incorporated into the Brazilian nation.

Besides having been used as labor during colonialism, Indians were, as is known, a key element in settlement policies as well as in the production and control of the Brazilian colonial territory. ${ }^{8}$ Upon the organization of the imperial independent State and of the ensuing Republican State, these populations, while relatively autonomous, challenged the sovereignty of the political apparatus that was in the process of establishing itself. A significant part of $19^{\text {th }}$ century constitutional provisions focused on territorial issues and

6 According to Banton, the First World War consolidated nationalism as one of the principles of world peace and led to the creation of the League of Nations. The Second World War strengthened this consensus and it eventually became the only political alternative for colonial independences (1975: 160-161).

$7 \quad$ For Foucault (2008), the 'population' issue emerged in the late $18^{\text {th }}$ century as the object of a new way of governing which conceives the 'population' as a State's main wealth and source of power.

8 Gabriel Aldren observes that the integration of indigenous populations to Luso-Brazilian armies was frequent during the colonial period. The alliance with the Portuguese guaranteed indigenous chiefs the possibility of maintaining autochthonous groups while ensuring some degree of participation in the hierarchical system of the colonial government. Blacks who participated in military conflicts were also granted the possibility of freedom as well as social insertion and mobility (2010: 146-148). The condition of being a slave was actually very complex and varied widely in terms of degree of autonomy and possibility of buying freedom according to the region and type of activity people engaged in (see Schwarcz 1996). 
tried to limit the occupation of the territory by indigenous peoples in order to retain a reserve of 'public lands' (Mares de Souza Filho 1992). In practice, the establishment of rights concerning public lands also produced rights over the natives' original lands. Indigenist models, either in the Christian missionary version or in Rondon's positivist view, always implied some form of preservation, limitation or modelling of territories perceived as pertaining to these people who had been originally born in Brazil. These populations were therefore not racialized in the $19^{\text {th }}$ century. The polarity that constituted them as national entities concerned their civilizational stage. Although their 'savagery' was supposed ultimately to give way to integration into the normativity of the State through the legal status of tutelage, indigenous "ancestry" in using the territory that connoted it was positively taken up and indelibly marked the imagination of the Brazilian nation. Brazil thus became imbued with a historical depth that preceded colonization by a foreign power.

Blacks, in contrast, emerged as a population within the political system: They interpellated the Republican State not because of their origin, but because of their condition, which was then perceived as contradictory: they

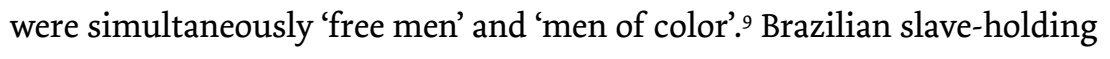
society had indelibly associated the condition of captivity to the black color and freedom to the white color. But, as noted by Gabriel Aladren (2010: 128-129), the existence and expansion of social groups with both the attributes that were in principle conceived of as exclusive and extreme led to miscegenation. Miscegenation was more than a biological process whose ancestry it was no longer possible to determine; it was above all a social process through which a new intermediary and uncomfortable place was produced in the social hierarchy. In contrast with the United States, the idea of freedom began to be outlined in Brazil with the abolitionist movement, and not in the religious field. It might be for this reason that, as suggested by Jose Murilo de Carvalho, "the values of individual freedom, which lie at the base of the civil rights that are so dear to European modernity and to the founders of North America, did not have a prominent role in Brazil" (2008:49). With the proclamation of the Republic, the abolitionist movement

$9 \quad$ Some population maps from the late $18^{\text {th }}$ century oppose the category of 'white' to that of 'slave.' According to Silvia Lara (2007), between these two categories were pardos (brown) and freed blacks. For her, this mass was perceived as a growing danger to the social order by the authorities because it was neither under the private authority of slave masters nor well-integrated into the social hierarchy. 
was weakened and replaced by a dispute for control over the practices that might be considered acceptable by courts, medical and public hygiene discourses, the press and public opinion, the Catholic hierarchy, etc. Many scholars have demonstrated how, in a slow and contradictory process of criminalization/assimilation/remodeling, popular practices associated with blacks during slavery, such as capoeira, ${ }^{10}$ certain rhythms and dances, cults and rites, were progressively modeled, reinvented, and incorporated by their practitioners, intellectuals, and scientific societies, as well as the political forces of the State, as constitutive indexes of nationality (Ortiz 1985, 1991; Dantas 1982; Souza Reis 1993, 1996, 1997).

This excursion into very complex and widely studied subjects such as slavery and miscegenation allows us to point out elements that are important for our argument: During almost 400 years the black 'color was intimately associated with the condition of slavery, even if not exclusively so." 'Intermediary colors' were classified based on the basis of phenotype rather than 'blood.' As has rightly been observed by Jack D. Forbes (1993), censuses of various Brazilian provinces during the $19^{\text {th }}$ century used the categories of pardo (brown), mestiço (mestizo), caboclo (of mixed Indian and black ancestry), and mulato (mulatto) in various ways. They did so primarily on subjective perceptions of possible tonalities in a relatively arbitrary way. It was only in the second half of the $19^{\text {th }}$ century that these tonalities were associated to the idea of 'race,' even if in a very impressionistic way because the ancestry of particular individuals was hardly retrievable..$^{12}$ According to Lilia Schwarcz (1993: 14), racial theories arrived late in Brazil, but were then welcomed with great enthusiasm by a scientific community marked by positivist and

$10 \quad$ Leticia Reis (1996: $42-43)$ observes that in Rio de Janeiro, capoeira, until the mid-19 ${ }^{\text {th }}$ century a phenomenon that was essentially associated to black slaves, eventually incorporated freed slaves, Portuguese and even whites of higher social standing. During the Second Empire its practitioners supported the monarchy, which caused them to be implacably persecuted by the Republicans. Efforts for the criminalization of capoeira date from this period, and it was finally criminalized in the 1890 Penal Code. Treating capoeira as a gymnastica, a legacy of miscegenation, and a sign of nationality were the arguments which, throughout the $20^{\text {th }}$ century, repeatedly served as a foundation for the process that transformed it into a national sport in the 1930s and 1940s (Reis 1997).

11 However, the black color could also be assigned different qualifications according to the slave's condition: crioulo (a black person born in Africa who could speak Portuguese well), ladino (a black person born in Brazil) or boçal (a black person born in Africa who could not speak Portuguese) (Schwarcz 1996: 19).

12 In O espetáculo das raças [The Spectacle of Races], Lilia Moritz Schwarcz (1993) provides a panoramic view of the trajectory of the concept of race from its arrival in the Brazilian scientific milieu in the late $19^{\text {th }}$ century to its decline in the 1930s. 
evolutionist ideas. But if the Brazilian nation chose social Darwinism as the foundation of social progress, its mixed nature did not favor adherence to the theoretical determinism implicit in these models. The biological theories on which the concept of racial superiority was grounded associated 'blood mixture' with all manner of degeneration, and did not provide any clear and widely acceptable ideological route for the political construction of a popular sovereignty grounded in the idea of race in a society that was marked by centuries of miscegenation.

Thus, in contrast with the United States and more recent States such as South Africa, which had race as the central element of their political and legal system as well as their national consciousness, part of the Brazilian men and women of letters drew on a tradition through which skin tonality designated a social condition marked by the free slave and possibilities of social mobility. They soon abandoned the excessively divisive ideology of 'race' or racial supremacy as a substratum for nationality and legal marker of difference. In effect, the acceptance of racial models started to decline already in the 1930s, and the experience of miscegenation became, as in Gilberto Freyre's paradigmatic work, the main reference for the cultural standard that formed the nation. ${ }^{13}$ As has rightly been observed by many scholars investigating the subject, among whom Antonio Sergio Guimaraes, Brazil developed a cultural politics that was explicitly based on miscegenation that lasted for at least three decades (2011: 265).

Half a century later, the constituent process initiated in the 1980 o led to a new and intense mobilization around racial issues in which color was again associated with the condition of social inequality. Inspired by the conquests of multicultural and ethnic movements, black leaders organized themselves to strengthen anti-racist legislation.

13 Of course this does not imply that the category has vanished from the national vocabulary. The idea of "racial types" was used in the scholarly literature, for example, in descriptions of regional characteristics, such as the qualification of Sao Paulo's bandeirantes (slave and fortune hunters who penetrated and colonized the Brazilian interior in the $17^{\text {th }}$ century) as "the race of giants," an expression coined by Saint-Hilaire in the early $19^{\text {th }}$ century. It also became generalized in common language as an expression denoting criticism of difficult temperament/behavior, such as in “ô raça!", for which an imperfect gloss would be "oh race!.” After the anti-racist consensus built in the post-war period, race was declared a "biological myth" and started to be predominantly studied as a sociological issue. As a field of knowledge in the human sciences, the concept of race gave way to the field of studies of "racial relations," which would not be based on the concept of race, but would seek to examine the relation between skin color and unfavorable social positions in the social structure. In Brazil, the black presence was, from the perspective of race, color, culture, religion, and class, a recurring item in the vast literature obsessed with the problem of how to transform a population into a people since the late $19^{\text {th }}$ century. 


\section{b. State, religion, civil society}

Differently from the relations between race, ethnicities, and the formation of nationality, the relations between religions and modern States have more historical depth. Before the formation of nation-states in the $19^{\text {th }}$ century, it is known that European populations were aggregated or divided according to their sovereigns' language, religion, region or kinship ties. There is relative consensus in the literature on the subject regarding the importance of the Peace of Augsburg in 1555. It put an end to the wars between Catholics and Protestants in Europe and thus contributed to the consolidation of the idea that to each State corresponds a Church, consecrating the principle of territorial and cult unity. Although the Thirty Years' War (1616-1648) momentarily interrupted this consensus, the Treaty of Westphalia ratified the principle according to which a State, a territory and an exclusive and dominant religion guaranteed by the power of the State would coincide. After this arrangement was made, in many cases, such as that of Henry VIII's England, the state power apparatus began to coincide with the religious apparatus and heresy was treated as political treason (Lecler 1955; Laursen 1998; Bauberot 1993). In the case of France, although the Edict of Nantes $(1598)^{14}$ established the co-existence of two confessions under the same State, its revocation by Louis XIV in 1685 made Catholicism once again the exclusive religion of a State territory at a moment in which political reforms weakened the jurisdiction of the Catholic Church over the French territory. ${ }^{15}$

The complexities and nuances of a process that lasted four centuries have already been described and analyzed by a vast literature that we do not intend to cover here. For the purposes of our argument, however, it is important to stress that the conflictive and/or harmonious relations between religions and the administrative powers of States contributed to demarcate the new space of civil society-that is, a space that concerns private subjects-and circumscribe relative rights, such as eligibility for public office, requirements for professional regulations, legal capacities, the registration of birth, marriage

14 Although the dispositions of the Edict of Nantes approved by Henry IV maintained Catholicism as the official religion of the kingdom as well as its ancient rights, properties, and incomes, it allowed Protestants to practice domestic worship and granted them certain civil rights, such as the guarantee of having their own courts and eligibility to public office. It also granted them political rights with the institution of protectorates guarded by Huguenots in 200 fortified places, among which were La Rochelle and Montpellier.

15 The Declaration of the Clergy of France, proclaimed in 1682, granted the king vast legal powers over the clergy and the property of the Church in France. 
and death, and, of course, freedom of worship. Thus, while the most recent ideas of 'race' and 'ethnicity' have been associated with the constitution of 'nationality' in somewhat well-established States, issues concerning religions have been historically associated with the very edification of the structures of modern secular States and their counterpart, civil society, as an entity of rights that was relatively separate from both the State and the religious apparatus. As has been well-observed by Geoffrey Levey, religion had a formative role in the development of liberal societies because it was the only idiom available. Thus, other cultural forms could only be distinguished from religious forms as time went on (2009:5). This difference of historical depth seems to be fundamental for us to understand the distinctive way in which "religions" and "ethnicities" politically interpellate the power of the State.

In a previous paper Montero 2013) that examines the strategic role of the Catholic Church in the construction of Republican secularism in Brazil, we argued that Christian culture also had a key role in the formation of the Brazilian public sphere. Thus, although the religious model and the model of the nation State obey distinct logics, the construction of secularism went hand in hand with the construction of nationality. In contrast to Protestantism, perceived as an imported religiosity, and to magical practices, associated principally with slavery, only Catholicism allowed for the celebration of the supposedly primordial bonds uniting the different members of the Brazilian nation. From an institutional perspective, the construction of the modern Republican State depended on the legal institution of a state apparatus that was separate from the ecclesiastical administration. However, in spite of the tensions brought about by the reform of the State undertaken by Republicanism and the accommodation of the goods and interests of the Catholic Church in civil legal associations, there was no war against religion in Brazil. On the contrary, many authors have already demonstrated that given the inception of a state bureaucracy that lacked technical and human resources, civil life remained for a long time under the aegis of religious administration (Beozzo 2000; Mainwaring 1989; Giumbelli 2000; Mariano 2002, Montero 2006, 2009). Forty years after the establishment of the new regime, the alliance between the Church and the State was to be further strengthened by the first term of Getulio Vargas's administration, which actively collaborated to establish the Catholic Church as the moral tutor of the Brazilian nation. By granting it privileges and subsidies in exchange for 
political and ideological support, Vargas's administration consolidated the material bases for the religious monopoly of Catholicism for a long time. The intimate relations between the Catholic Church and the State endured until their relative rupture during the military regime from 1964 onwards. As has been well-observed by Ken Serbin (1999: 7), this moral agreement made it possible for the Catholic Church to become "the social extension of the State by means of the construction of hospitals, churches, and other projects."

For these reasons, the naturalization of Catholicism as a moral value of the Brazilian nation permeated all spheres of social life for more than half a century. It was in its name that Catholic priests, with the connivance of sectors of the Judiciary, colonized the institutions, laws, powers of the State, and public celebrations, persecuting pastors and popular practice, which, they believed, threatened the social and moral order. In practice, the State depended on Christian culture and ecclesiastical institutions to formulate a unifying ideology of Brazilian nationality, a process that continued over various decades. Politically, the Catholic Church maintained its influence over an expressive part of the dynamics related to the construction of citizenship by maintaining control over social welfare and expanding its hegemony over civil rights.

The moral agreement with the Catholic Church eventually became the model of legal reference for the creation, organization, and recognition of new civil religious associations that disputed the adherence of popular classes. In effect, categories such as 'magic,' 'sorcery,' and 'macumba' were organized in a generic way within the classification of 'low Spiritism' and understood as the reverse of religion. They were typified as crimes until the 1940s (Giumbelli 1997). Giumbelli argues that it is in the realm of debate with the agents of the law that Spiritism and Umbanda were constructed as religions by banning from their practices elements such as animal sacrifice, economic exploitation, and magical healing, which were legally framed as charlatanism and quackery. ${ }^{16}$ One might also add that the fact that such practices were considered as crimes in the penal code indicates how the legal semiology of Christianity regarding possession and sorcery was, side by side with medicine, able to keep part of its legal powers until a relatively recent period.

16 The author observes that in the Northeast, differently from what happened in the South, the concept of 'African religions' was constructed through dialogue with intellectuals (1997: 272-273). 
This quick digression through the notions of race and ethnicity in their relation to issues of nationality as well as through the category of religion in its relation to the formation of secularism allow us to perceive how the categories of 'religion' and 'ethnicity' have followed parallel trajectories in their relation to the construction of modern nation States. While race/ethnicity are categories that, each in its own way, aim to include cultural differences within the idea of the nation, secularism has since the $17^{\text {th }}$ century been considered a legal solution for conflicts involving religious differences. In the Brazilian case, in which religious diversity had not yet constituted itself as such, secularism had much more the role of legally guaranteeing the effective separation of the bureaucratic and political interests of the Republican State and the Catholic Church than it had, for lack of actual religious competition, the role of exerting pressure for the withdrawal of religion from the public sphere.

However, the notions of secularism and race return to the core of the present political dispute, in which the secular national State, submitted to the double scrutiny of internal and external pressure, becomes the object of intense criticism, which is aimed at bringing about greater equality and the recognition of differences. In effect, pressure for more participation and political influence on the part of movements centered on religious and ethnic demands affect the contemporary understanding of secularism, on the one hand, and nationality, on the other..

Thus, let us consider the contemporary scenario in order to understand how 'secularism' and 'pluralism' have, in locating 'religions' and 'ethnicities' within the realm of political struggles, given rise to new challenges for what we could call 'post-secular' and 'post-national' States, as defined by J. Habermas. ${ }^{17}$

\section{New challenges to the sovereignty of post-secular States}

In a previous article in which we examined the issues of religious pluralism and ethnographic translation in the light of the Habermasian concepts of

17 In the 2008 seminar organized by Reset Dialogue on Civilization in Istanbul, J. Habermas describes the affluent societies in Europe and America as 'post-secular.' The term has both a descriptive dimension, in that it refers to the affluent societies in Europe and America in which religions demand an active role in public controversies, and a normative dimension. The author tries to respond to the challenge of thinking of how it is possible for democratic institutions to guarantee the construction of a political community based on the ethical pluralism of various religions. See "A post-secular society. What does that mean?" In: http:/|www.resetdoc.org/ story/0ooooooog26. (Accessed on November 3, 2013). As for the issue of post-national states dealt with by Habermas in the context of immigration, see The Post-National Constellation. Political Essays. Littera-Mundi, 2001. 
publicity and reflexivity, we faced the contemporary theoretical and political challenge of the necessary co-existence of cultural and religious differences within a common legal framework (Montero 2009). In Law and Democracy, Habermas (1992) suggests that in post-World War II secular societies, law took on the function of mediating between the communicative power that lies at the foundation of the society and the administrative power, in this way removing a prerogative maintained by the Catholic Church for many centuries. However, the dramatic events that occurred on September 11 in the United States challenge secularism as a model and have led thinkers and philosophers to reformulate the question of the 'resurgence of religion' in the secular world. According to Habermas (2008), a strictly secular model that associates accelerated modernization with the vanishing of religion cannot confront the problem posed by post-secular societies, in which religions demand the right to influence the public sphere.

\section{a. Secularism and religious pluralism}

The secularism of the Brazilian state has been guaranteed by its Constitution for over one century. However, secularism has never been as threatened as in the last decade, during which various sectors of civil society have invoked the principle of secularism to demand respect for difference of faith and freedom of worship. Some have mobilized opinion to enforce the removal of religious symbols from public places, while Neo-Pentecostal leaders have initiated an aggressive campaign against Afro-Brazilian religious manifestations. ${ }^{18} \mathrm{How}$ could one explain the present visibility and intensity of the public controversy over secularism and religious intolerance?

Since the Republican Constitution of 1891, Brazil has recognized freedom of worship and prohibited any State interference in religious affairs.

18 In 2007 the Committee for Combating Religious Intolerance in Brazil was founded in Rio de Janeiro Legislative Assembly to mediate conflicts between Evangelicals and Afro-Brazilians. In December 2009 the National Human Rights Program presented by the federal government proposed, among other measures, to "prevent the ostensible display of religious symbols in the Union's public bodies." In 2013, the Federal Attorney's Office demanded, in the name of State secularism, that the expression "May God be praised" be removed from the new Real bills. Also in March 2013 the Committee for the Constitution, Justice, and Citizenship judged as admissible the proposal for a constitutional amendment by deputy João Campos (PSDB) from Goiás, which includes national religious organizations (National Conference of Brazilian Bishops, Supreme Council of the Presbyterian Church in Brazil and Baptist Convention) among the ones that can propose Direct Unconstitutionality Actions, a prerogative that had been restricted to political organizations and labor unions. The same year witnessed intense mobilization against the appointment of Evangelical deputy Marco Feliciano (PSC) as the president of the Human Rights and Minorities Committee for the sake of State secularism. 
However, its purpose at that time was practically to guarantee civil autonomy to Catholicism and freedom of worship to Protestants. As has already been argued (Montero 2009), while the civil code aimed at consolidating secularism by separating civil acts (birth, marriage, education, health, etc.) from the civil effects until then guaranteed by the Christian sacraments (baptism, marriage, last rites), the penal code, in contrast, regulated practices that challenged 'order,' 'public morality,' and 'civility.' In this sense, it is possible to affirm that the historical process of the construction of secularism in Brazil developed more rapidly than the production of a religious pluralism that simultaneously recognized the existence of different religions and the effective right to freedom of faith and worship. In effect, as we shall see below, in the Brazilian case, religious diversity was very slowly transformed into political pluralism due to the Catholic hegemony that until very recently delayed the emergence of conflicts over secularism in Brazil.

As far as secularism is concerned, the 1988 Constitution basically limited itself to what had already been foreseen in the previous Constitutions (Leite 2012:158). However, it did include a small but significant change to the article concerning the protection of 'free external manifestation of faith' (Art. 5, VI). It suppressed the references to 'public order' and 'good morals' as limits to the practice of religious worship. We believe that this suppression expresses the understanding that Spiritism and Afro-Brazilian practices had become, over the previous fifty years, widely accepted as unequivocally religious activities that should therefore have the full right of public expression. We could therefore conclude that the 1988 Constitution represents a milestone concerning the widening of the notion of religion on the part of the State by recognizing practices that were previously subject to criminalization as fully religious, and by accepting religious pluralism as a right that demands respect for differences of belief and the defense of freedom of worship. (Leite 2012:61). Paradoxically, the dispute over the very concept of secularism was exacerbated exactly when religious pluralism and its rights were recognized. Increase in the competition between possible creeds and the incorporation of the idea of the free manifestation of opinions as an individual right multiply the different positions regarding practices that may be considered acceptable or not within a secular State.

As far as religious pluralism is concerned, Evangelical growth has increased the perception of religious diversity, as has already been mentioned, 
and the conflict between Neo-Pentecostals and Afro-Brazilian religions has place the right to the manifestation of worship at the core of the dispute. In reality, it seems that the institutionalization of religious pluralism as a legal issue and social practice has been paradoxically stimulated by the very expansion of Pentecostalism. The latter, in its strategy of confronting other religions, has displaced religious conflict from the State-which has suspended its penal restrictions-to civil society, which now disputes individual religious choices on behalf of the freedom of conscience and manifestation.

In fact, by publicly demonizing other forms of worship in the name of 'truth' and 'sin,' ${ }^{19}$ some sectors of the Neo-Pentecostal movement resort to a dogmatic language similar to the language of Catholic priests in their campaigns against Umbanda in the 1950 in order to circumscribe religious frontiers and expand their symbolic domain over Afro-Spiritist manifestations. But what was then accepted by public opinion without much scandal now causes a profound confrontation of opinions. In fact, as is shown by Milton Bortoleto's investigation in progress, organized religious leaders have drawn on the 1989 anti-racist law that actions undertaken in the name of the 'true religion' should be understood as prejudiced and typified as criminal. ${ }^{20}$ It is now no longer possible to "not recognize what is practiced by some churches as religion," as intended by pastor Tupirani, the mentor of Afonso Henrique, the youth who destroyed images in a Spiritist center in Rio de Janeiro.

\section{b. Secularism and the ethical foundation of the State}

While there have been no significant changes in the law on secularism, the Executive has produced new policy directives, particularly in the 2009 version of the federal government's National Program for Human Rights. The document expressed demands from both secular and religious sectors and included a measure that aimed to develop actions "to preclude the

19 Declaration posted on You Tube in 2009 by one of the youths who invaded the Spiritist Center Cruz de Oxala according to the narrative published in Milton Bortoleto's work (2013). In the narrative by Afonso Henrique, who attends the Imperio Geração de Jesus Cristo church, he affirms that he felt "challenged" by the attendants of the Spiritist Center, and therefore entered it and asked for the demons: "Where are they so that I can stamp over their heads and prove that Jesus Christ is greater and sovereign"? Mutatis mutandi this narrative is not very different from Catholic missionaries' narratives on the magical forces mobilized by the indigenous chiefs they intended to convince of the greater power of God. See http://frecab.com.br/2012/07/ condenados-fanaticos-religiosos/

20 Typification was facilitated by the new wording of the anti-racism law (L7716) passed by President Sarney in 1989. In 1997 prejudice against ethnicity and religion was added to prejudice against race and color as crimes liable to be punished in accordance with the law. 
ostensive display of religious symbols in the Union's public buildings as a way of promoting the secularism of the State as well as respect for differences of faith and worship" (Giumbelli 2012: 45). The proposal did not last long: it was removed from the document in a new decree less than one year later. It revealed the distinction between secularism understood as the legal separation of State and Church and secularism understood as the secular self-representation of nationality, a distinction that is deeply ingrained in the imagination of various sectors of the Brazilian society.

In the reverse direction of the National Human Rights Program, the growth of Evangelical churches challenges the Catholic imagination for greater influence in public life. Protestants, and especially Neo-Pentecostals, compete in various fields-in Parliament, in the media, on the streets-for the monopoly over religion and against Catholic hegemony as a mediating force, together with law, between society and the State apparatus.

The episode in which sculptures were broken by a Neo-Pentecostal youth at a Spiritist center described in the press in 2009 provides a good illustration of the dispute for the mediating role between society and State (Bortoleto 2013). In Afonso Henrique's narrative of how he was arrested and taken to the police station, he affirms that policemen "think they are an authority, but they are not," and reiterates that "for the Church they are no authority." Pastor Tupirani, his mentor at the Igreja Geração de Jesus Cristo church goes even further by heading a campaign called "Yes, Bible! No Constitution!" ${ }^{21}$ Such propositions seem to challenge the legal sovereignty of the State itself in that they reignite the subject of secularism as a dispute between the State and Religion.

Although this position might be considered very marginal in the field of religious controversies in Brazil today, it still makes us face the sensitive issue of the ethical foundation of our legal system. The political utopias related to the construction of Brazilian democracy-equality, freedom, citizenship-no longer seem to be able (if they have ever been) to fulfill the set of ideas that uphold the ethical foundations of the judicial order. The debate

21 Demonstration on the waterfront of Copacabana in June 19th, 2012. The pastor affirms in his speech: “Geração de Jesus Cristo church does not bow to men's law! Their sentence has no value. I spit and tear, just as I have torn various documents and symbols of documents. I can tear law. And I could easily tear the Constitution itself. Because I have the right to follow the law I want.” See http://www.youtube.com/watch?v=E_Lq8q5JhTY. Consulted on December 5th, 2013. 
on the removal of crucifixes and their persistent permanence in courts and public buildings suggest the continuity of Catholicism as a cornerstone of civic life. ${ }^{22}$ Thus, the process of its denaturalization (and consequently of its persuasive power) as an ethical foundation began at the very moment in which its presence became the object of fierce dispute. The data collected by Ranquetat Jr. (2012: 70-75) in his work on the presence of religious symbols in public spaces seem however to indicate that it is easier for law operators to accept the introduction of competing religious symbols, such as the Bible, in public spaces than to support their complete removal, as demanded by atheist movements. The Resolution Project Nr. 49 of 1988 approved an amendment authorizing the placing of Bibles on the plenary table of the Chamber of Deputies "as a source of inspiration and spiritual subsidy for the task of elaborating rules and laws." Of course this is not the same as to affirm the intention of "tearing up the Constitution." Although Christianity disputes within itself the privilege of being the moral foundation of Brazilian society, the data seem to indicate that this justification can only present itself publicly as non-religious: "The Bible is not to be confused with religion," affirmed Antonio de Jesus, the Evangelical constituent deputy who proposed the amendment.

Thus, if the conflict between religions has led to a normative reinforcement of pluralism, as stated above, how may one understand the affirmation of the autonomy of religious law over civil jurisdiction? How shall one understand this persistent permanence of religion as a civil bond despite the acceptance of the diversity of faith as a principle? Why does it seem to be more difficult to practice tolerance regarding different faiths than regarding different cultures? Is it possible to deal with religious pluralism at the same legal level as that which regulates ethnic pluralism?

In reality, the problem of religious pluralism seems to be far more complex. Differently from cultural pluralism, which questions civil and collective rights, campaigns such as “Yes, Bible! No Constitution!" led by pastor Tupirani of the Igreja Geração de Jesus Cristo church seem to challenge the very democratic foundation of the liberal model of the State that supposes freedom of expression to be the ethical foundation of modern society, as

22 In an interview to Ranquetat Jr., Wambert Di Lorenzo, professor of Law at the Pontifical Catholic University of Rio Grande do Sul, affirms that "when a crucifix is found in a public building, the first thing it reminds us of is that that State or that state environment is at the service of society" (2012: 66). 
suggested by Binoche (2012). What is thus reintroduced in its place is religious consensus or the primacy of a hegemonic religion.

In view of these ways of expressing religious convictions, some NeoPentecostal currents might be compared to certain Muslim movements in Europe, which, as in the case of the cartoon controversy, take the sharia as the legal foundation for violent reactions against journalists and the press. In the case of Neo-Pentecostalism, the pastor who affirms that "the law of his God is the noblest of all" in the name of the right to the freedom of public expression of faith also places religious law above civil law. He thus seems to question the very legal foundation of the secular State. From our perspective, this view has not been adequately assessed by Modood (2009) in his critique of the secularist ideology of multiculturalism and his demand for the introduction of anti-blasphemy laws in England. Now, according to the example cited here, the pastor's enunciation combines respect for difference of beliefwhich is at the level of individual freedom-not with respect for difference of opinion, but with the right to "follow the law I want"-which is located at the level of the ethical foundation of normativity. Thus affirmed, this demand places us before the aporia that consists of demanding respect for the right of individual freedom (of expression) while questioning the legal foundation of all democratic rights.

The challenges posed by the recognition of religious minorities are not, therefore, of the same nature as those posed by the recognition of ethnic minorities. Let us take a quick glance at the challenges that the recognition of minorities as ethnic groups poses to the political field.

\section{Challenges to the sovereignty of post-national States}

In a previous paper (Montero 2012), I developed the idea, already hinted at by authors such as Costa (2006), Arruti (2005), and French (2002), that the phenomena of ethnic identities, having taken the field of culture (as the emanation of a group's way of being) as a starting point, have projected themselves into the field of politics by means of an appropriation of the grammar of law. By so doing, they have resulted in the legalization of ethnic groups. For this to become possible it was historically necessary for a set of agents to emergeanthropologists, missionaries, journalists, lawyers, activists, ethnic leaders, etc. These agents were responsible for doing the creative work of mediation 
that transforms memories, accounts, and ways of living into a legal cause. This process of legalization of ethnic identities is related to a broader debate in the contemporary world context, which opposes multiculturalism to the classical idea of nation States.

According to Charles Taylor (2009), the original notion of multiculturalism alluded, at least in the Canadian case, to a procedure of integration. However, according to him, it became in many countries a suspicious and misunderstood term because it was supposed that it implied an unlimited expansion of different forms of living in a national society, thus fragmenting it into different ghettos and threatening its fundamental values. For Taylor this fear is absurd in view of the enormous assimilating force of liberal societies; this force would compel communities willing to keep their way of life fully original to isolation (2009: xiv). Anyway, although we do not wish to take sides on this debate, it seems that by about the end of the $20^{\text {th }}$ century it was already clear that international conditions-economic and migration flows, the consolidation of political blocks, environmental issues, etc.- had weakened the classical idea of nation States and their regulatory framework. A legal understanding of the positive discrimination of differences eventually became crystalized in this international political context, which started to promote anti-assimilationist policies.

In the Brazilian case, the new legal and political framework inaugurated with the 1988 Constitution partly anticipated the concerns related to the revision of the international norms on indigenous peoples defined in the Indigenous and Tribal Peoples OIT Convention 169 of 1989, which recognized “the Indians' social organization, customs, languages, believes and traditions as well as their original rights over the lands where they have traditionally lived; the Union shall demarcate the land, protect them and provide for the respect of all their goods" (Montero 2012). This transformation affects the very formulation of nationality. The Brazilian State, until very recently imbued with the national ideology of assimilationism as a model of social coherence, began to see itself as a State made up of parallel and pluriethnic heritages. Ethnic pluralism started to use the language of the 'recognition of the right to cultural difference' and to establish a fourth generation of rights to citizenship besides civil, political, and social rights: collective rights such as the recognition of traditional territories, social diversity, respect towards the environment and biodiversity, etc. (Arruda 2005: 100). The conviction 
that indigenous populations-and also traditional communities-protect the forests in which their territories have been partly recognized and delimited was then established. ${ }^{23}$ In the case of the Brazilian Northeast, Arruti (2002) has shown that after democratization in the 1980s, the historical "struggle for land" reappeared in the political scenario in the garments of an ethnic language that introduced cultural differences as a mobilizing force, following the indigenist movement of the previous decade.

In this sense, it is possible to affirm that the Brazilian version of 'multiculturalism' re-substantializes the idea of race and ethnicizes cultures which syncretism had mixed. This ethnicization process is developed mainly in relation to the struggle for land. This eventually re-elaborates the idea of inclusion and social cohesion, which is here associated with the creation of specific territories delimited by the State. The latter become a relatively autonomous political and administrative unit regarding natural resources and the management of daily life, but remain connected to the State apparatus that continues to be the main channel of access to external resources (Arruti 2002: 9). This notion of "ethnic territories" was adopted by Catholic missionaries linked to the Indigenist Missionary Council (CIMI). Allied with sectors of the academic and political fields, they began training indigenous leaders and creating civil organizations. Thus, the legacy of the connection between territory and indigenous populations that marked colonial history was taken as a reference and "rural workers" and "caboclos" started to be treated as descendants of Indians ("índios remanescentes") who progressively gained collective rights to the ownership of land through the medium of a culturalist vocabulary. In the 199os, this same process was extended to black rural populations, which were ethnically recognized as communities descending from fugitive slaves (remanescentes de quilombos), that is, no longer individuals pertaining to a race, but bearers of a collective way of life associated with a particular territory.

In spite of the resistances and tensions that are still part of the dispute for the recognition of this new class of rights, one could argue that it was once more through the maintenance of the grammar of the construction of nationality, that is, through the association of an idea of "culture" as a

23 I have tried to demonstrate the importance of environmentalist causes for the success of the legal legitimation of territorial demands on ethnic grounds in the Amazon region elsewhere (Montero 2012: 91). 
collective way of life to a national (or subnational) territory that racial and ethnic differences were accommodated within the very legal framework of the State. Although the Brazilian State has assumed "ethnicity" as an indicator for the recognition of minorities, it has never abandoned its prerogatives to define the national territory as well as its collective purposes, as has been well demonstrated by Pacheco de Oliveira (1999).

It is noteworthy that in the debates that characterize the final decades of the last century, the category of "indigenous nations" then mobilized by various leaders and movements progressively disappeared and was replaced by "peoples" and "communities," categories stabilized in the 1988 Constitution. Such categories express the understanding widespread at various levels of Brazilian society that the possibility for the recognition of parallel and autonomous legal and political apparatuses for indigenous populations was not on the agenda. In fact, the oxymoron "federal ethnicities," coined by the Federal Attorney when solving a conflict between the Xocó Indians and the Mocambo village (Arruti 2006), illustrates well how national territoriality has provided the mental framework that guides the Brazilian legal and political system in the assimilation of the international public consensus that ethnic minorities should be protected and granted rights. In this political construction, the conjunction between ethnicity and territory has provided the normative framework within which differences can be incorporated into nationality. In this way, public and private civil rights are accommodated without threatening governance, territorial unity, and the sovereignty of the judicial apparatus.

\section{Final considerations}

The differences in historical depth and political implications greatly explain the persistent difficulties in granting religious minorities the same collective rights and forms of legal protection that have already been granted ethnic minorities. Modood (2009: 169-73) observes that until very recently it was impossible to penalize discrimination against Muslims in England because they were not considered to be an ethnic group. It was necessary for the English legal framework, which has always incorporated the concept of "race," to be expanded in the 196os so that "ethnic" groups such as the Pakistanis might be allowed citizenship and legal protection. This extension 
eventually displaced the idea of the equality of individuals with the notion of the equality of collectivities. Still, the author observes that Muslim activists do not fit well into the category of "ethnicity" and demand equality and public recognition in terms of their religious practices. Therefore, according to the author, there is a gap between the advances in the field of ethnic equality and those concerning religious equality. Religious Muslims are thus not authorized to represent themselves collectively as such.

In the course of our argument, we have tried to elucidate the main elements that contribute to this gap. In the first place, one has to consider the differences of nature and temporality between the construction of civil and collective rights. This distinction allows one to understand why, in contrast to the rights of ethnic minorities that have been granted the right to express themselves collectively in respect for their traditions, the rights of religious minorities fall into the purview of civil rights and individual freedoms regarding issues of opinion and consciousness that supposedly belong to the private sphere.

In the Brazilian case, we have seen that the 1988 Constitution redefined the legal framework of the nation State by recognizing ethnic identities and granting them particular rights. However, although this ethnicization of color differences has been constructed in contrast to the language of syncretism and reinstated the concept of 'race' at least as a language of rights, it did not abandon the integrating principle of nationality. At the same time, as has been well-observed by authors such as Antonio Sergio Guimaraes $(2011)^{24}$ and Peter Fry $(1995,1996)$, the category of "race" has been reinstated in the political and academic language as well as in governmental censuses as a social classifier and a language of rights. Thus, differently from what happened in the field of ethnicity, "race" and "culture" seem to be separated once more in the religious field. Religions of "African" origin become closer to anti-racist political movements. ${ }^{25}$ In the past, some practices perceived as having an

24 For Antonio Sergio Guimaraes, the term "race" has been reinstated in the language of activists and social scientists who consider the notion of "ethnic identity" to be insufficient to deal with a social discourse that resorts to physical markers of classification (2011:266). In contrast, Peter Fry $(1995,1996)$ considers the growing racialization of popular practices to be an effect of political engagement and of the practices of an academic sector that tends to consider the black/white polarization a more efficient instrument to combat racism.

25 The bill which instituted November $15^{\text {th }}$ as the National Day of Umbanda and was signed by President Dilma Roussef in 2012 bases its justification on the constitutional right to the freedom of belief and the free practice of religious worship, according to subsection VI of art 5 of the Brazilian Constitution, and emphasizes the Brazilian character of this religion (which has been granted a celebrative date in the national calendar). 
"African" origin were recognized as religions because they were considered part of the Brazilian national tradition. They have therefore been conceived of within the framework of collective rights. In this case, it is noteworthy that the dispute arose not in the religious field, as respect for 'freedom of conscience' and pluralism, at an individual and private level, but in the cultural field, in which the notion of 'national tradition' that interpellates the collective and public level presided over the process in which the legitimacy of such practices was recognized.

Still, as far as the long duration is concerned, we have mentioned that non-Christian practices were constituted as legitimate religions. Once constituted, however, religious diversity was not immediately converted into the political language of religious pluralism. On the contrary, Catholicism had a long historical hegemony and campaigned against Spiritism, Umbanda, and Candomble until the late 196os. The fact that Catholicism was deeply ingrained in the self-representation of Brazilian national culture prevented it from confronting State secularism. Respect for religious pluralism was also restricted, except for a few exceptions involving Protestantism. Thus, it was possible to build a historical consensus regarding a pact for secularismwhich implied the separation of State jurisdiction from the Catholic legal apparatus-and to simultaneously attribute a considerable part of the leadership in the secularization processes to Catholic agency: that is, the separation of civil society from the State. In effect, the Catholic grammar is so deeply ingrained in the secularization process that of its referents, such as crucifixes, images, and churches, became part of the language of civil society and cultural heritage. In this sense, it might be affirmed that the social and political dynamics that stimulated the advance of secularism in Brazilian society did not immediately lead to religious pluralism as a political language, that is, to the recognition of religious choice as a fact of opinion and, consequently, to the respect for equality between the different religions as legitimate mediators of society before the State. For this same reason, it was never possible for Afro-Brazilian practices to dispute the field of ethical normativity of the State

However, the institutionalization of the date published on the website of the Secretary for Politics Promoting Racial Equality in Brazil, an agency created in 2003 whose delegate is the black minister and activist Luiza Helena de Barros, points out its African roots and tries to converge the defense of religious freedom with the "protection of the rights of individuals and ethnic groups, especially those of the black population, affected by racial discrimination and other forms of intolerance." 
as religions. On the contrary, when their rights to the freedom of manifesting their faith were attacked by Neo-Pentecostal action, it was in the field of anti-racial struggles that they found the most effective way of defending their civil rights and denouncing what they saw as the crime committed against them. Thus, pluralism inaugurates religious disputes that paradoxically send "African traditions" back to the field of racial grammar.

If we now turn to the issue of "religious minorities," it becomes clearer why the challenges pluralism poses to the Brazilian State could not be solved by accommodating differences within nationality, as in the case of multiculturalism. Although the secularism of the State was defined early in the Brazilian case, it took time for religious pluralism to become a political language. As has been observed, it has been closely associated to the deterritorialization and, as a consequence, the denationalization of religion in order to allow differences to co-exist. This was guaranteed by the neutrality of the State in relation to different faiths. The denationalization of Catholicism has only recently taken shape, and religious controversies are a fundamental instrument in this process. Neo-Pentecostals play a significant role by pointing to the fact that Brazil's identification with Catholicism is due to historical accident.

Jose Murilo de Carvalho (2008:10-13) rightly suggests that rights have been granted especially on the initiative of the State in Brazil and that this has been one of the most distinctive characteristics of Brazilian citizenship. In particular, greater emphasis has been placed on social rights than civil and political rights. These characteristics might explain why the multiculturalist agenda may be more rapidly absorbed even before the clearly consolidated institution of a pluralist society in the religious field, a field that interpellates individual rights. In effect, as has already been mentioned, due to the way in which religion and culture have been historically articulated in Brazil, the idea of "freedom" has been related to anti-slavery struggles, and not to the religious disputes that, in the European case, led religious freedom to antecede other rights.

In the context of the forces and interests described above, we would affirm that the expansion of Neo-Pentecostal Protestantism causes new tensions to emerge at two different levels in contemporary Brazil: the legal acceptance of religious pluralism as a recognition of the regulated disagreement of publicly expressed opinions; and a reaffirmation of secularism that implies the privatization of religion, that is, the total suppression of religious 
symbols from public places. However, as the classical liberal model of democracy-for which the idea of "public opinion" is an effect of the idea of "private religion," as suggested by Binoche (2012)-has been otherwise reconfigured in Brazil, where Catholicism constitutes what is public in the form of civil society, nationality, and/or tradition, pluralism reintroduces religious conflict as a dispute for the consensus on "true religion" as an ethical foundation for social life.

Thus, by rejecting the ethnic condition of Afro-Brazilians and confronting their religion as "false" in the religious field, Neo-Pentecostals seem to introduce a "holy war" into the political agenda, sending the issue of the individual rights of blacks back into the religious field. For this reason, in recent episodes of confrontation with Afro-Brazilian religiosity, NeoPentecostals reinserted a controversy over secularism in the political agenda of the last two decades, which seemed to have already been duly dealt with. Their recurring and aggressive presence in the public sphere cannot be explained, as has been frequently affirmed in the literature, by the weakness of Brazilian secularism, which is characterized by the way State and civil society allow themselves to be 'invaded' by religion. To us, these issues do not concern the relations between society and the State, as was the case in the past, when crimes against 'public credulity' and 'sorcery' were formulated regarding 'false religions.' Since then, 'false religions' have been recognized and have organized themselves into various civil institutions. As mentioned above, the Brazilian constitutions have granted them freedom of worship and the neutrality of the State.

Thus, although the debate on secularism is old, the present context of the secularization of Brazilian society leads us to affirm that we are actually in the presence of a new phenomenon. In the past, the dispute over secularism concerned the autonomy of the State apparatus in relation to the Catholic ecclesiastical apparatus and the authorization, in the name of 'freedom of worship', for the creation of schools and foundation of churches by Protestants. It does not seem that these are exactly the questions that motivate disputes around secularism today. Therefore, Brazil faces a very paradoxical situation, in which the dynamics of religious pluralism advance by means of public actions which, in the case of the Neo-Pentecostals, do not recognize as religious practices many of those that have been historically recognized as such. The agenda of freedom of consciousness becomes an issue 
through its confrontation with the agenda of collective rights for the respect of differences. Secularism advances in that it makes the ethical foundation of the State a little more plural, even if still in debt to Christian culture.

However, it seems clear to us that one issue remains open: on the one hand, to respond to the dilemma posed by Charles Taylor regarding the nonself-sufficiency of the secular and, on the other hand, to define the type of respect deserved by those who live under the jurisdiction of religious laws (Modood 2009: 220). The religious controversies activated by Neo-Pentecostal movements partly concern the dispute between Afro-Brazilian and Catholic religions for the ethical foundation of Brazilian nationality. Upon observation of the constant manifestations of Neo-Pentecostal churches, especially the Universal Church of the Kingdom of God, one might notice why, in a way that is very similar to the European reaction to Muslims, Neo-Pentecostal pastors revive in Brazil the old controversy over the secularism of the State. While Muslims in Europe seem to challenge the founding parameters of European secularism by demanding to publicly use religious insignia or by demanding that 'blasphemy' be recognized as a crime (Modood 2009), the Brazilian neo-Pentecostals do so by encouraging their adherents to invade Spiritist and/or Umbandist centers and break their images (Bortoleto 2013), by legislating in their own interest, for example when ordering Bibles to be placed in public spaces (Ranquetat Jr. 2012), or by supporting proposals for the criminalization of animal sacrifice (Bortoleto 2013). The cases analyzed here allow us to propose that as religious ethics remains the foundation for civil life in Brazilian society, even if in a diffuse way, the less positive the relation between religion and nationality is, the greater will be the chance that its normativity be perceived as theocratic, and therefore a threat to the collective normativity of the State. On the other hand, we have observed that the racial issue was partially subsumed and accommodated at the level of collective rights in Brazil-either as tradition, as in the case of Afro-Brazilian religions, or at the level of territory, as in the case of the quilombo movement. Placing African religions in the field of individual rights by classifyingng them as "religious minorities" would mean reinserting them into the dispute for the ethical foundation of nationality and collective morality, a context in which they would certainly lose. In contrast, reinserting them into the field of individual rights by classing them as "racial minorities" has been relatively more successful due to the implementation of affirmative policies. Yet, debate on 
the political and social effects of this legal interference with the classification system remains intense.

The examples above help us to demonstrate that the political relations implied by religious pluralism as a political language are different from and frequently contradictory with those implied by multiculturalism. If the law is able to successfully carry out its role as a mediator between social dynamics and the administrative apparatus by legalizing ethnic identities, religious pluralism tends to dispute this mediating role with the law by multiplying the available ethical references.

Translated from the Portuguese by Iracema Dulley Received January 01, 2014; approved July 01, 2014.

\section{Referências Bibliográficas}

ALADRÉN, Gabriel. 2010. "Pretos e pardos no sul da América portuguesa". In: Celia Cristina da Silva Tavares e Rogério de Oliveira Ribas (orgs.), Hierarquia raça e mobilidade social. Rio de Janeiro: Contracapa. 125-139. ARRUDA, Rinaldo. 2005. "Territórios indígenas no Brasil: aspectos jurídicos e socioculturais". In: Marlon Salomon e Joana A. Fernandes \& Leandro Rocha Silva (orgs.), Processos de territorialização. Entre a história e a antropologia. Goiânia: Universidade Católica. 81-104

ARRUTI, José Maurício. 2003. De como a Cultura se faz Política e vice-versa: sobre religiões, festas negritudes e indianidades no Nordeste contemporâneo. IV CICLO NAÇÃO E REGIÃO - Brasil 500 anos - Experiência e destino. FUNART/UERJ e UENF.

ARRUTI, José Maurício. 2006. Mocambo: antropologia e história do processo de formação quilambola. São Paulo: Edusc.

BANTON, Michael. 1975. A idéia de raça. Lisboa: Edições 70.

BAUBÉRAUT, Jean. 1993. "Estratégias da liberdade”. In: C. Sahel (org.), A tolerância. Porto Alegre: L\&PM. 78-9o

BEOZZO, José Oscar 200o. Religião e estado na história do Brasil. Belo Horizonte: Veredas.

BINOCHE, Bertrand. 2012. Religion Privée, Opinion Publique. Paris: Libriarie Philosophique.

BORTOLETO, Milton. 2013a. "Não cultuais imagens de escultura". Alguns aspectos do debate público acerca da tipificação jurídica da 'intolerância religiosa' e da 
'liberdade religiosa'. São Paulo. Mimeo

BORTOLETO, Milton. 2013b. "Não viemos para fazer aliança”. Conflito religioso entre pentecostais e afrobrasileiros na esfera pública. São Paulo. Relatório de qualificação, USP.

CARVALHO, José Murilo de. 2008. Cidadania no Brasil. O longo caminho. Rio de Janeiro: Civilização Brasileira.

COSTA, Sérgio. 2006. Dois Atlânticos: teoria social, antiracismo,cosmopolitismo. São Paulo: Humanitas.

CARNEIRO DA CUNHA, Manuela. 1986. Antropologia do Brasil: mito, história e etnicidade. São Paulo: Brasiliense/Edusp.

CARNEIRO DA CUNHA, Manuela. 2009. Cultura com aspas. São Paulo: Cosac Naify.

CARNEIRO DA CUNHA, Manuela. 1987. O direito dos índios: ensaios e documentos. São Paulo: Brasiliense.

DANTAS, Beatriz Góes. 1982. "Repensando a pureza nagô”. Religião e Sociedade, 8: $15-20$

DUBOW, Saul. 1995. Scientific racism in modern South Africa. Cambridge: University of Cambridge.

DULLEY, Iracema. 2013 “A historiografia sobre a 'conversão' nas missões protestantes e a trajetória de Jesse Chiula Chipenda” Paper presented at seminar entitled "Problemas historiográficos da África colonial portuguesa e da África pós-colonial de língua oficial portuguesa, University of São Paulo, October.

FARAGE, Nadia. 1991 [1986]. As muralhas dos Sertões: os povos indígenas no Rio Branco e a colonização. São Paulo: Paz e Terra.

FILHO, Carlos Frederico Marés de Souza. 1992. "O direito envergonhado: o direito dos índios no Brasil”. In: Luís D. B. Grupioni (org.), Índios no Brasil. São Paulo: Secretaria Municipal de Cultura. 153-168

FORBES, Jack D. 1993. Africans and native Americans: the language of race and the evolution of red-blacks peoples. Chicago: University of Illinois Press.

FOUCAULT, Michel. 2008. Segurança, território, população. São Paulo: Martins Fontes.

FRENCH, Jan Hoffman. 2002. Legalizing identities. Becoming black or indian in Brazil's Northeast. Chapel Hill: The University of Caroline Press.

FRY, Peter. 1995/96. "O que a cinderela negra tem a dizer sobre a 'politica racial' no Brasil". Revista USP 28: 122-135 
FRENCH, Jan Hoffman. 2005. A persistência da raça: ensaios antropológicos sobre o Brasil e a África austral. Rio de Janeiro: Civilização Brasileira. GASPARD, Françoise. 1993. "Racisme et nationalité”. In: Michel Wieviorka (org.), Racisme et modernité. Paris: Éditions La Découverte. 152-158 GIUMBELLI, Emerson. 1997. O Cuidado dos Mortos: Uma história da condenação e legitimação do Espiritismo. Rio de Janeiro: Arquivo Nacional,

GIUMBELLI, Emerson. 2012. “Crucifixos em recintos estatais e monumento do Cristo Redentor: distintas relações entre símbolos religiosos e espaços públicos”. In: Carlos Alberto Steil, Roberto Cipriani, Emerson Giumbelli, Ari Pedro Oro (orgs.), A religião no espaço público: atores e objetos. São Paulo: Terceiro Nome. 45-6o

HABERMAS, Jünger. 1997. Direito e democracia. Rio de Janeiro, Tempo Brasileiro.

HABERMAS, Jünger. 2008. "A post-secular society: what does that mean?" Reset Dialogues on Civilizations. August 13, 2008, http://www.reset.doc.org/ EN/Habermas-Istanbul.php,accessed August 13, 2008.

LARA, Silvia. 2006. Fragmentos setecentistas: escravidão, cultura e poder na América portuguesa. São Paulo: Cia. das Letras.

LAURSEN, John. 1998. "Baylean liberalism: tolerance requires non tolerance”. In: C. Narderman e J. Laursen (eds.), Beyond the persecuting society. religious tolerations befor the Enlightenment. Philadelphia: University of Philadelphia Press. 197-215

LECLER, Joseph. 1955. Histoire de la tolérance au siècle de la réforme. Paris: Ed. Montaigne.

LEITE, Fabio Carvalho. 2012. "Liberdade religiosa e objeção de consciência: o problema do respeito aos dias de guarda”. In: Carlos Alberto Steil, Roberto Cipriani, ORO, Ari Pedro, GIUMBELLI Emerson, STEIL Carlos Alberto, CIPRIANI Roberto; (orgs.) A religião no espaço público: atores e objetos. São Paulo: Terceiro Nome.

LEVEY, Geoffrey Brahm. 2009. "Secularism and religion in multicultural age”. In: Geoffrey Brahm Levey and Tariq Modood (eds.), Secularism, religion and multicultural citizenship. Cambridge: Cambridge University Press. 1-24

MAINWARING, Scott. 1989. Igreja católica e política no Brasil:1916-1985. São Paulo: Brasiliense.

MILES, Robert. 1993. "Racisme institutionnel et rapports de classe: une relation problématíque" In: Michel Wievioka (org.), Racisme et modernité. 
Paris: Éditions La Découverte. 159-175

MODOOD, Tariq. 2009. "Muslim, religious equality and secularism".

In: Geoffrey Brahm and Tari Modood (orgs.), Secularism, religion and multicultural citizenship. Cambridge: Cambridge University Press. 164-185

MONTEIRO, John. 1994. Negros da terra. Índios e bandeirantes na formação de São Paulo. São Paulo: Cia das Letras.

MONTERO, Paula. In press. "Secularism and Religion in the Public Sphere in Contemporary Brazil” in: Betina Schmidt Ed.), The Brill Handbook of Contemporary Religions in Brazil. Leiden: Brill

MONTERO, Paula. 2009. "Jünger Habermas: religião,diversidade cultural e publicidade". Novos Estudos Cebrap, 84:. 199-213

MONTERO, Paula. 2012. "Multiculturalismo, identidades discursivas e espaço público”. Sociologia e Antropologia, 2: 81-101

MONTERO, Paula. 2006. "Religião, pluralismo e esfera pública no Brasil”. Novos Estudos Cebrap, 74: 47-65

MONTERO, Paula. 2009. "Secularização e espaço público a reinvenção do pluralismo religioso no Brasil”. Etnográfica, 13(1): 7-16

MONTERO, Paula. 2012. Selvagens, civilizados, autênticos: a produção das diferenças nas etnografias salesiana (1920-1970). São Paulo: Edusp.

NOBRE, Marcos \& TERRA, Ricardo. 2008. Direito e democracia.Um guia de leitura de Habermas. São Paulo: Malheiros.

OLIVEIRA, João Pacheco de. 1999. A viagem de volta: etnicidade, política e reelaboração cultural no Nordeste indígena. Rio de Janeiro: Contracapa.

OLIVEIRA, Roberto Cardoso de. 1976. Identidade, etnia e estrutura social. São Paulo: Pioneira.

ORTIZ, Renato. 1991. A morte branca do feiticeiro negro. São Paulo: Brasiliense. 2a. edição.

ORTIZ, Renato. 1985. Cultura brasileira e identidade nacional. São Paulo: Brasiliense.

REIS, Letícia Vidor de Sousa. 1993. Negros e brancos no jogo de capoeira: a reinvenção da tradição. Dissertação de Mestrado, São Paulo, Universidade de Sâo Paulo.

REIS, Letícia Vidor de Sousa. 1996. "Negro em terra de branco: a reinvenção da identidade". In: Lilia Moritz Schwarcz e Letícia Vidor de Sousa Reis (orgs.), Negras imagens. São Paulo: Edusp. 31-53

REIS, Letícia Vidor de Sousa. 1997. O mundo de pernas para o ar. São Paulo: 
Publisher.

ROCHA PINTO, Paulo Gabriel Hilu da. 2005. "Ritual, etnicidade e identidade religiosa nas comunidades muçulmanas no Brasil”. Revista Usp, 67:. 228-249

ROMERO, Mariza. 2008. Inúteis e perigosas: o Diário da Noite e as representações das classes populares. Tese de Doutoramento, PUC-São Paulo.

SCHWARCZ, Lilia Moritz. 1993. O espetáculo das raças.Cientistas, instituições e questão racial no Brasil 1870-1930. São Paulo: Cia. das Letras.

SCHWARCZ, Lilia Moritz. 1996. "Ser peça, ser coisa: definições e especificidades da escravidão no Brasil”. In: Lilia Moritz Schwarcz e Letícia Vidor de Sousa Reis (orgs.), Negras imagens. São Paulo: Edusp. 11-29

SERBIN, Kenneth. 1999. The Catholic Church, religious pluralism and democracy in Brazil. s.l. : Kellogg Institute.

SINGER, Lester. 1962. "Ethnogenesis and Negro-Americans today". Social Research, 29: 419-432

SOUZA FILHO, Carlos Frederico Marés de, 1994, “O direito envergonhado: o direito e os índios no Brasil”, em Luís Donisete Benzi Grupioni (org.), Índios no Brasil. Brasília, Ministério da Educação e do Desporto, 153-178

TAYLOR, Charles. 2009. "What is secularism?” In: Geoffrey Brahm Levey and Tariq Modood (orgs.), Secularism, religion and multiculturalism. Cambrigde: Cambridge University Press. 